\title{
High ascorbic acid content in the rat endocrine pancreas
}

\author{
A. Zhou and N. A. Thorn \\ Danish Government Biotechnology Centre for Neuropeptide Research, Department of Medical Physiology C, University of Copenhagen, \\ Copenhagen, Denmark
}

\begin{abstract}
Summary. The peptidyl alpha-amidation of biologically active peptides (a number of which are found in the endocrine pancreas) requires several co-factors, including ascorbic acid. In the present study, tissue contents and developmental changes of ascorbic acid in the rat endocrine panreas were measured using a highly sensitive HPLC system. High concentrations were found in neonatal rats, with the highest value, $42.5 \mathrm{nmol} / \mathrm{mg}$ protein, in 2 -day-old rats. The concentration decreased gradually with age to $19.4 \mathrm{nmol} / \mathrm{mg}$ in 5 week-old rats. The exocrine pancreas had a lower concentration, but a peak was also observed in 2-day-old rats. In freshly isolated islet cells, an intracellular concentration of $7.5 \mathrm{mmol} / 1$ was estimated in 5-7-day-old rats. Secretory gra-
\end{abstract}

nules isolated from 4-6-day-old rat islets contained $10.6 \mathrm{nmol} / \mathrm{mg}$ protein. Culturing islets or cells in ascorbic acid free medium resulted in a marked decrease in their contents. Ascorbic acid in secretory granules from such islets decreased at a relatively lower rate. Addition of ascorbic acid to cultured cells or islets reduced the loss markedly. Increasing the glucose concentration in islet culture medium in the presence of $100 \mu \mathrm{mol} / \mathrm{l}$ ascorbic acid increased the islet ascorbic acid concentration.

Key words: Ascorbic acid, islets of Langerhans, rat, diabetes mellitus.
Ascorbic acid (AA), vitamin C, is a ketolactone with a strong potential as an electron donor, especially in the presence of copper and iron. It appears to be involved in many processes such as reactions catalysed by monooxygenases and dioxygenases, and it is one of the most potent co-factors for the peptidyl alpha-amidating enzyme [1]. It has been demonstrated in several tissues, e.g. rat pituitary, that availability of AA to the tissue is a rate-controlling factor in the production of amidated peptide hormones.

The consideration of a role for AA in pancreatic islets has been restricted to glucose homeostasis in diabetes and its possible role in the polyol pathway. A number of amidated regulatory peptides are found in the endocrine pancreas, e.g. thyrotropin-releasing hormone, pancreatic polypeptide, amylin and pancreastatin, and expression of amidating enzyme activity and its characteristics have recently been reported $[2,3]$. We have reported [4] that cells from pancreatic islets of neonatal rats can take up AA via a carrier-mediated, high affinity, specific and active transport system. There was a more than ten-fold concentration gradient across the plasma membrane.

In the present study we have measured AA in rat pancreatic islets, islet cells and secretory granules as well as in the exocrine pancreas, and studied the influence of certain factors on tissue AA contents.

\section{Materials and methods}

Preparation of isolated pancreatic islets, dispersed islet cells, beta-granule enriched fraction and exocrine tissue

Pan-Wistar rats were maintained on a standard diet containing $36 \mu \mathrm{g}$ of AA per gramme. Islet isolation, cell dispersion from isolated islets, islet culture and cell incubation were performed as previously described [4].

Islets and exocrine tissue were separated after treatment of pancreatic tissue with collagenase $(5 \mathrm{mg} / \mathrm{ml})$ for $15 \mathrm{~min}$, by subjecting the digests to a pre-generated discontinuous Ficoll (Ficoll 400, Pharmacia, Uppsala, Sweden) gradient and then centrifuged $(800 \mathrm{~g}$ for 10 min., brake off). Exocrine tissues were collected when required. Isolated islets were further enriched by manual selection. Ficoll was excluded by washing with preparation buffer (modified Hanks' Balanced Salt Solution, composition (mmol/l): $\mathrm{CaCl}_{2} 1.26, \mathrm{KCl} 5.37$, $\mathrm{KH}_{2} \mathrm{PO}_{4} 0.44, \mathrm{MgCl}_{2} 0.49, \mathrm{MgSO}_{4} 0.41, \mathrm{NaCl} 136.89, \mathrm{NaHCO}_{3} 4.17$, $\mathrm{Na}_{2} \mathrm{HPO}_{4}$ 0.34, glucose 5.05 and Hepes 20.00, pH 7.4).

Secretory granules were prepared by the method of Jones et al. [5]. In brief, the isolated islets were homogenized in a buffer of $10 \mathrm{mmol} / 1$ Mops (3-[N-Morpholino]propane sulphonate acid), 
$260 \mathrm{mmol} / \mathrm{l}$ sucrose, $\mathrm{pH} 6.5$ with the homogenates then being subjected to two centrifugation steps. The resulting granule-enriched pellets were used directly for AA analysis.

\section{Measurement of $A A$}

AA was analysed by an HPLC system combined with a coulometric detector [6] with minor modifications. Briefly, the system employed a biocompatible binary pump (Gilson 250, Perkin Elmer, Norwalk, Conn., USA), a pressure sensor (Gilson 802B, Perkin Elmer), a coulochem detector (ESA Model $5100 \mathrm{~A}$ with a 5011 high sensitivity analytical cell, ESA, Bedford, Mass., USA) and a data integrator with a Model 900 interface (Perkin Elmer). The stationary phase was a $3 \mu \mathrm{m} \mathrm{C}_{18}$ ODS (octadecyisilane) spherisorb analytical column $(4.6 \mathrm{~mm} \times 10 \mathrm{~cm}$, Mikrolab, Århus, Denmark), preceded by a $7 \mu \mathrm{m}$ $\mathrm{C}_{18}$ ODS guard column $(3.2 \mathrm{~mm} \times 1.5 \mathrm{~cm}$, Perkin Elmer $)$. In-line high-pressure carbon fiber pre-filters (ESA) were located in the positions preceding the injector, the guard column and the analytical cell. The mobile phase consisted of $0.05 \mathrm{~mol} / \mathrm{l}$ sodium phosphate, $0.05 \mathrm{~mol} / \mathrm{l}$ sodium acetate, $189 \mu \mathrm{mol} / \mathrm{l}$ dodecyltrimethylammonium chloride and $3.66 \mu \mathrm{mol} / \mathrm{l}$ tetraoctyl-ammonium bromide in $30 / 70$ methanol/water (volume/volume), $\mathrm{pH} 4.8$ by phosphoric acid, filtered prior to use through a $0.22 \mu \mathrm{m}$ Millipore filter. Detector settings were: $1:+0.00 \mathrm{~V}, 2:+0.40 \mathrm{~V}$. Gains are given in Results. Due to the limited amount of islet tissue, samples were loaded on the system through a manual injector ( $20 \mu \mathrm{l}$ loop, Perkin Elmer). For all operations, water filtered through a Milli-O Plus water purification system (Millipore, Bedford, Mass., USA) was used.

In the original method paper, it was stated that methanol did not interfere with the AA assay in this system. However, we have occasionally observed a poor separation of AA and methanol. It was also observed that using $0.5 \%$ metaphosphoric acid as solvent for standard or extraction/storage solution for biological samples could give lower noise, compared with methanol/water/EDTA at the same gain. Therefore, in the present study, the solvent/extraction/storage solution for standard and biological samples was either methanol/water/EDTA or $0.5 \%$ metaphosphoric acid, as indicated in Results. In both cases, samples were vortexed thoroughly, centrifuged at $20,000 \mathrm{~g}$ for $30 \mathrm{~min}$, and the supernatants filtered through a $0.22 \mu \mathrm{m}$ filter before being applied to the HPLC system. Routinely, analysis of AA was carried out immediately after the samples were ready. In a few cases they were kept at $-20^{\circ} \mathrm{C}$ in storage solution for not longer than a week (it has been checked that AA contents remained stable during that time-period).

Preliminary experiments showed that resin extraction (to exclude the interference of catecholamines) did not result in significant differences in AA analysis using the present system. Consequently, this step was omitted.

\section{Statistical analysis}

Unless indicated, all data are presented as mean \pm SEM, with the number of individual preparations or experiments $(n)$. Statistical computations were made using RS1 software (BBN Software Products Corporation, Cambridge, Mass., USA).

\section{Results}

\section{Contents of AA in rat pancreas: exocrine tissue, isolated} islets, islet cells and beta-granules

Figure 1 represents a typical chromatogram from the present analytical system. Figure 2 shows the developmental changes of AA concentrations in rat pancreatic islets and exocrine tissue. In islets a value as high as $42.5 \pm 7.3 \mathrm{nmol} / \mathrm{mg}$ protein $(n=4)$ was found on the second day after birth. The contents then decreased grad-

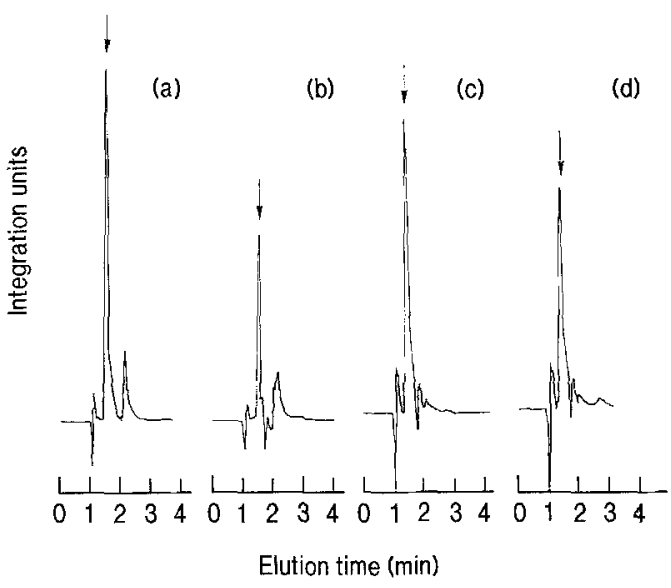

Fig. 1a-d. HPLC analysis of Ascorbic acid (AA). The analytical procedure was as described in Materials and Methods. a $85.2 \mathrm{pmol}$ $\mathrm{AA}$ in $30 \%$ methanol/water/1 mol/l EDTA (gain $100 \times 4$ ); b Islet homogenates (4-day-old rats) in $30 \%$ methanol/water $/ 1 \mathrm{mmol} / 1$ EDTA (gain $100 \times 4$ ); c 14 pmol AA in $0.25 \%$ metaphosphoric acid (gain $100 \times 20$ ); d 4-day-old rat islet homogenates in $0.25 \%$ metaphosphoric acid (gain $100 \times 20$ ). The position of AA is marked by $(\downarrow)$

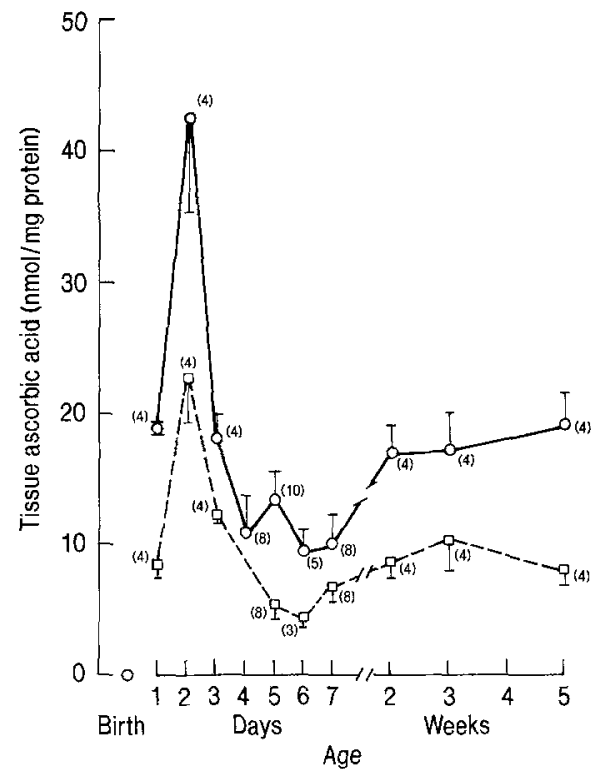

Fig. 2. Ascorbic acid (AA) content in rat pancreatic islets and exocrine pancreas during development. Islets (solid line) and exocrine tissue (dotted line) from pancreata of rats of different ages were separated, washed with $0.9 \% \mathrm{NaCl}$ and extracted with either methanol/water/EDTA or $0.5 \%$ metaphosphoric acid. AA was analysed by an HPLC system with a coulometric detector. Data are presented as mean $\pm S E M$ with the number of animals indicated in parentheses

ually until day 6 . From the second week to the fifth week the contents became relatively stable. The changes in exocrine tissue showed similar trends, but the concentrations were considerably lower than those of endocrine tissue throughout the period studied.

Isolated cells from islets of 5-7-day-old rats contained $1.6 \pm 0.4 \mathrm{nmol} / 10^{6}$ cells $(n=7)$ (about $8.7 \mathrm{nmol} / \mathrm{mg}$ protein). Assuming an intracellular water space of $0.21 \mu \mathrm{l} / 10^{6}$ cells [2] and free distribution of AA, the concentration of AA would be $7.5 \pm 1.7 \mathrm{mmol} / \mathrm{l}$. 
Secretory granules from 4-6-day-old islets contained $10.6 \pm 3.1 \mathrm{nmol} / \mathrm{mg}$ protein AA, while the concentration in relevant islet homogenates was $8.5 \pm 2.8 \mathrm{nmol} / \mathrm{mg}$ $(n=3)$. AA in the granule fraction amounted to $7.2 \%$ of total islet content.

\section{AA concentrations in islet cultures and incubated cells}

When islets from 5-7-day-old rats were cultured in media without extrinsic AA for up to 5 days, the tissue AA content decreased time-dependently. For example, prior to and on the first and fifth day of culture, the content was $22.3 \pm 2.8(n=7), 3.5 \pm 0.7(n=4)$ and $1.6 \pm 0.3(n=3)$ $\mathrm{nmol} / \mathrm{mg}$ protein, respectively. Adding AA to culture media up to a concentration of $100 \mu \mathrm{mol} / \mathrm{l}$ could prevent the loss to a certain degree - on the first and fifth day, it was $28.8 \pm 3.8(n=5)$ and $10.4 \pm 2.3(n=3) \mathrm{nmol} / \mathrm{mg}$ protein $(p=0.001$ and 0.02 when compared with the corresponding group without AA), respectively. To compensate for the degradation of extrinsic AA during culture, which could be as high as $90 \%$ in $24 \mathrm{~h}$, the culture media were changed twice per day.

When cells from freshly prepared islets were suspended in a buffer without AA, the cellular AA decreased in hours. The most significant loss took place in the first $2 \mathrm{~h}$ (from $1.6 \pm 0.4 \mathrm{nmol} / 10^{6}$ cells $(n=7)$ to $0.25 \pm 0.1$ $\mathrm{nmol} / 10^{6}$ cells $(n=5)$. The addition of $100 \mu \mathrm{mol} / \mathrm{l} \mathrm{AA}$ to cell suspensions resulted in substantially higher cellular concentrations.

The AA content in secretory granules from overnight cultured islets of 4-6-day-old rats was $5.6 \pm 0.5 \mathrm{nmol} / \mathrm{mg}$ protein $(n=3)$, which was about $53 \%$ of the amount prior to culture.

\section{Influence of glucose on AA concentration in islet cultures}

Isolated islets from 4-6-day-old rats were cultured overnight in media containing $100 \mu \mathrm{mol} / 1 \mathrm{AA}$ and 0,5 or $15 \mathrm{mmol} / \mathrm{l}$ glucose. In islets cultured with 5 and $15 \mathrm{mmol} / \mathrm{l}$ glucose, the AA content was $148.5 \pm 33.2 \% \quad(p=0.31$, $n=5)$ and $176.4 \pm 44.4 \%(p=0.02, n=5)$ of that with $0 \mathrm{mmol} / \mathrm{l}$ glucose, respectively).

\section{Discussion}

Previous studies of AA in the pancreas have been limited to using whole pancreas. We have reported that AA content in the pancreas of neonatal rats was about $10 \mathrm{nmol} / \mathrm{mg}$ protein, using a fluorometric method. An intracellular concentration of $3.5 \mathrm{mmol} / 1$ was estimated in islet cells [4]. Due to the high sensitivity of the present method, we were able to analyse AA in routine preparations, without pooling of samples. The high contents found are comparable with those of bovine neural and intermediate pituitary tissues. A secretory granule content of $10.6 \mathrm{nmol} / \mathrm{mg}$ protein in rat pancreatic islets is also comparable to that in granules from bovine pituitaries and adrenal medulla.
In man, the AA content of the pancreas is about 20 to $50 \%$ of that of the pituitary or adrenal glands. Although data from other rat tissues using the present analytical system are not available for comparison, the estimated cellular concentration in islet cells is comparable to concentrations found in the primary cultures of rat anterior and intermediate pituitaries. If we consider the contents of peptideamides and the activities of amidating enzyme in rat endocrine pancreas and pituitaries, it is not surprising that high concentrations of AA were observed in pancreatic islets in the present study. For example, rat pars intermedia of the hypophysis contains $2-5 \mathrm{pmol} / \mathrm{\mu g}$ protein of pro-adrenocorticotropic hormone/endorphin-derived peptides including alpha-melanophore stimulating hormone, a tissue-specific peptideamide [7]. Pancreatic islets of neonatal rats have the highest concentration of thyrotropin-releasing hormone, $22 \mathrm{fmol} /$ islet or $0.22 \mathrm{pmol} / \mathrm{\mu g}$ protein [8] (assuming $0.1 \mu \mathrm{g}$ protein per islet). Islets of adult rats contained $233.6 \mathrm{fmol} /$ islet amylin immunoactive substance [9] or $1.2 \mathrm{pmol} / \mu \mathrm{g}$ protein (assuming $0.2 \mu \mathrm{g}$ protein per islet). These two peptideamides are only representatives of total peptideamides in islet tissue. The amidating activities in tissue homogenates and purified secretory granules from these tissues are of the same order of magnitude (unpublished results).

The pattern of developmental changes of AA concentration in pancreatic islets looks similar to that of amidating activity and mRNA for the amidating enzyme [10]. Thus, amidating enzyme activity might be the determining factor for AA requirement. For the kinetic parameters of AA uptake $\left(\mathrm{V}_{\max }\right.$ and $\left.\mathrm{K}_{\mathrm{m}}\right)$, however, there are no significant changes during the neonatal period (unpublished results). Cells from adult rat islets even showed a higher potential in accumulating AA (higher $V_{\max }$ and lower $\mathrm{K}_{\mathrm{m}}$, unpublished results). Since changes of AA concentration in the exocrine pancreas had a similar pattern, other developmental factors seem to be involved in regulating tissue AA content.

Secretory granules from neonatal rat islets had a considerable AA content, but this amounts to less than $10 \%$ of total cellular AA (we also observed that the granule fraction from ${ }^{14} \mathrm{C}$-AA loaded cells contained $6.8 \pm 1.3 \%$ of total cellular radioactivity. $n=6$, unpublished results). Thus, there must be other intracellular pools of AA, most likely comprising the mitochondria fraction [4]. The fact that the rate of decline of AA content in islet cultures was faster than in granules from such cultures might indicate the presence of an intermediate step between the extra- and intragranular compartments which could maintain intragranular concentration. The nature of this step and a possible involvement of mitochondria is obscure.

Similar to the effect of glucose on AA uptake to isolated islet cells [4], increased tissue AA contents were observed in islet cultures with increased glucose concentrations in culture media.

Acknowledgements. This project was supported by the A.P.Møller og Hustru Chastine McKinney Møllers Fond til Almene Formål, the Alfred Benzon Foundation and the Nordisk Insulin Foundation. The excellent technical assistance from Ms.B.L.Christensen is gratefully acknowledged. 


\section{References}

1. Eipper BA, Mains RE (1988) Peptide $\alpha$-amidation. Ann Rev Physiol 50: 333-344

2. Scharfmann R, Leduque P, Aratan-Spire S, Dubois P, Basmaciogullari A, Czernichow P (1988) Persistence of peptidylglycine $\alpha$-amidating monooxygenase activity and elevated thyrotropinreleasing hormone concentrations in fetal rat islets in culture. Endocrinology 123: 1329-1334

3. Zhou A, Thorn NA (1990) Evidence for presence of peptide $\alpha$ amidating activity in pancreatic islets from neonatal rats. Biochem J 267:253-256

4. Zhou A, Nielsen JH, Farver O, Thorn NA (1991) Transport of ascorbic acid and dehydroascorbic acid by pancreatic islet cells from neonatal rats. Biochem J 274: 739-744

5. Jones PM, Saermark T, Howell SL (1987) A small-scale method for the isolation of insulin-containing secretory granules from islets of Langerhans. Anal Biochem 166: 142-149

6. Washko PW, Hartzell WO, Levine M (1989) Ascorbic acid analysis using high-performance liquid chromatography with coulometric electrochemical detection. Anal Biochem 181: 276-282

7. Mains RE, Eipper BA (1979) Synthesis and secretion of corticotropins, melanotropins, and endorphins by rat intermediate pituitary cells. J Biol Chem 254: 7885-7894
8. Dolva L $\varnothing$, Nielsen JH, Welinder BS, Hanssen KF (1983) Biosynthesis and release of thyrotropin releasing hormone immunoreactivity in rat pancreatic islets in organ culture. J Clin Invest 72 : $1867-1873$

9. Kanatsuka A, Makino H, Ohsawa $\mathrm{H}$ et al. (1989) Secretion of islet amyloid polypeptide in response to glucose. FEBS Lett 259: 199-201

10. Meltese JY, Giraud P, Kowalski C et al. (1989) Ontogenetic expression of peptidyl-glycine $\alpha$-amidating monooxygenase mRNA in the rat pancreas. Biochem Biophys Res Commun 158: 244-250

Received: 8 July 1991

and in revised form: 19 August 1991

Prof. N.A. Thorn

Department of Medical Physiology C

University of Copenhagen

Panum Institute

Blegdamsvej; 3C

DK-2200 Copenhagen $\mathrm{N}$

Denmark 